\title{
Spatial Distribution of Omah Alas, Tanjungsari District, Karst of Gunung Sewu
}

\author{
Hilary Reinhart ${ }^{1 *}$, Shabrina Tamimi $^{2}$, and Nadhine Salsa Maulita ${ }^{3}$ \\ ${ }^{1}$ Department of Development Geography, Faculty of Geography, Universitas Gadjah Mada \\ ${ }^{2}$ Alumnae of Master of Architecture Study Program, Department of Architecture and Planning, Faculty of Engineering, Universitas \\ Gadjah Mada \\ ${ }^{3}$ Urban and Regional Planning Program Study, Department of Architecture and Planning, Faculty of Engineering, Universitas Gadjah \\ Mada
}

\begin{abstract}
Amid the arid characteristics and limited soil and land resources in the karst area to support the agriculture sector, the settlers in it strive and establish Omah Alas settlement as part of the adaptation and livelihood. Nevertheless, the study on the spatial distribution of Omah Alas as a unique type of settlement where every single house is scattered in a distance and located in the field is very few. This study specifically examines the spatial distribution of Omah Alas in Karst of Gunung Sewu and the factors behind it. Specifically, this study takes place at the Kemadang and Banjarejo Village, Tanjungsari District, and targets the farmers for the population and using purposive sampling aims those who spend their daily life in their field. The data are obtained using field survey, interview, and observation for the primary data and Peta Rupa Bumi Indonesia (RBI) for the secondary data. Those data are analyzed using nearest neighborhood analysis and kernel density. The results show how the village setting influences the accumulation of Omah Alas while the Omah Alas spatial distribution is random due to the irregularity of landform in the study area. Land use and land ownership also affect spatial distribution.
\end{abstract}

\section{Introduction}

In general, humans have interacted with the karst landscape and extracted its resource from time through time. As a landscape, karst provides water, dwelling places like rock shelter, rocks as a building material, and land to be cultivated. This practice of cultivation leads humans to develop a certain agricultural system in karstic areas worldwide [1-4]. Agriculture is considered one the most fundamental activities for the human to maintain their livelihood and shapes the society they live in since it provides the basic needs of food and energy. It requires several elements from the ecosystem such as water, soil, seed, and land. Every element that is needed can be found in the karst area. Nevertheless, karst itself is a fragile environment [5] with its vulnerability [6]. As an interaction between humans and the karst landscape, agriculture inevitably applies a certain threat to the karst environment and eventually will affect the human as well. Agriculture is a complex system full of uncertainty hence farmers and peasants at Karst of Gunung Sewu are urged to adapt accordingly to the environment.

The unique morphology and morphostructure $[7,8]$ of sinusoid hills in this area demand optimization of the doline area and the sloppy hills of the karst to be used. Not only facing its morphology setting, farmers and peasant at Karst of Gunung Sewu also must overcome the challenges from the thin soil, scarcity of water, and weather uncertainty while controlling the environmental impact of agriculture to the environment. The agriculture at Karst of Gunung Sewu could impact the karst environment by eroding its soil and leads to rocky desertification [9]. Further, agriculture practice is also one of the causes of groundwater pollution in the karst area [10] due to its poor filtration and hydrological characteristics. All those obstacles force farmers at Karst of Gunung Sewu to conduct a particular livelihood to adapt and sustain their life a daily basis [11]. Sustainable livelihood is the fundamental requirement since the karst area is highly fragile and must be managed with care and precaution. The whole process of adaptation is originally included in karst management and further, produces specific adaptation from economical adaptation [12] to landscape and physical modification [13].

Previous studies have successfully identified an adaptation toward climate change $[14,15]$. The hydrological characteristics with conduit and porous bedrock make run-off at the surface is very limited hence it is very difficult to build a proper irrigation system. Agriculture depends mostly on rainfall. Thus, the agriculture sector is prone to climate change and may result to crop failure or even arid. The adaptation toward land scarcity was studied by Uhlig [16] in Karst of Gunung Sewu discovered how agriculture utilized and optimized the area of sloppy hills known as highland

\footnotetext{
* Corresponding author: hilary.reinhart@ugm.ac.id
} 
agriculture and the doline area or known as lowland agriculture. Each slope part contains different species and has its biodiversity which is a special characteristic in the karst landscape [17]. Another form of human adaptation toward the physical environment is the settlement.

The settlement as the mode of adaptation had been practiced since prehistoric times [18] and agriculture is one of the factors that affect it [19]. Apart from that, settlement is also adjusted by concerning social and cultural function [20]. As a unique landscape, the karst environment also determines the settlement from its typology to its quality. The factors that determine settlement in the karst area are (i) physical, (ii) man, (iii) society, (iv) shell, and (v) network [21] while the factors that have a significant role in the quality of settlement are socio-economic and daily revenue [22]. In short, the intrinsic characteristic of karst is very fundamental to the relation of adaptation - agriculture - settlement.

This paper aims to scrutinize the spatial distribution settlement of Omah Alas in Tanjungsari District, Gunungkidul Regency, and the factors that affect it. The term of Omah Alas was coined by Tamimi [23] and refers to temporary buildings, off the grid in the field (or 'Alas', farmers in Tanjungsari District refer to their field as 'Alas'. 'Alas' means forest in English or 'hutan' in Indonesian) that are mostly dwelled. This phenomenon is unique and very limited studies have ever been conducted toward it. Omah Alas have strategic roles in agricultural activities where they provide shelter and make the work time for the farmers more efficiently since they do not have to commute daily from their permanent house in the village hence cut the production cost while helping the land resource management. Omah Alas is also effective in maintaining farmers's assets such as farming utensils, food crops, and livestock [23]. To examine the Omah Alas, this paper would grasp the notions of settlement and deal with the research question of how Omah Alas spatial distribution is and what are the influences of that spatial distribution.

\section{Methods}

To answer the research question and achieve the research purpose, this paper will use the cartography and Geographic Information System tool to help visualize and analyze the data. The analysis is done using Nearest Neighborhood Analysis (NNA) and the kernel density to determine the spatial distribution pattern of Omah Alas

\subsection{Research Location}

\subsubsection{Karst of Gunung Sewu}

Karst area, consisting of carbonate and evaporate rocks, encompasses roughly $20 \%$ of the non-ice earth's surface [24]. This landscape is mainly controlled by climate, lithology, and land cover factors. Thus, every karst region in the earth has its unique properties, strongly depending on the climate and lithology where it is situated as they would affect the dissolution rate and rock weathering to the morphology of the karst. One of the most prominent karst areas in the world is Karst of Gunung Sewu, tropical karst located at Southern Part of Java Island and extends to almost $120 \mathrm{~km}$ from west to east covering three regencies of Gunungkidul, Pacitan, and Wonogiri in three different provinces of DI Yogyakarta, Central Java, and East Java. Karst of Gunung Sewu is well known for its significant value of morphology, geology, and archaeology [25]. It has been inhabited since the Paleolithic era [26] and along with the advancement of civilization, agriculture is practiced in Karst of Gunung Sewu. Visualization of Karst of Gunung Sewu landscape can be seen in Fig. 1 below.

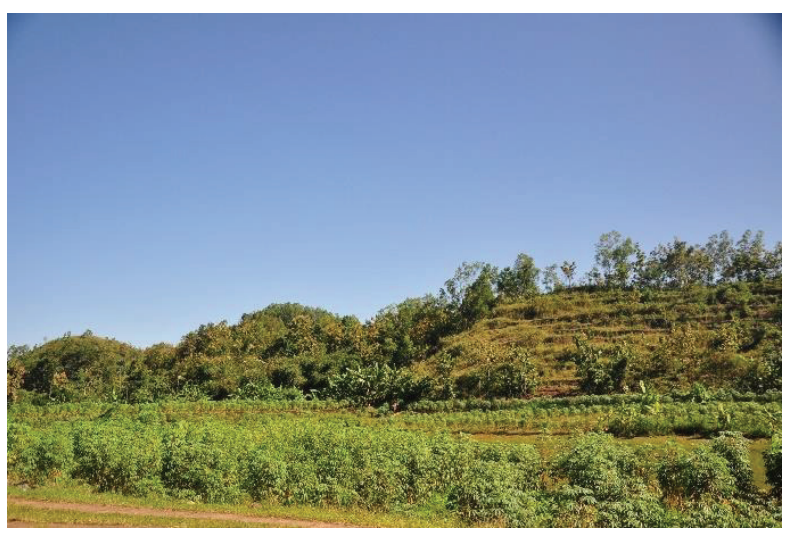

Fig. 1. Karst of Gunung Sewu Landscape (source: documentation, 2015)

\subsubsection{Kemadang and Banjarejo Village, Tanjungsari District}

Kemadang and Banjarejo Village are two of the villages in Tanjungsari District, Gunungkidul Regency with a total area of $19 \mathrm{~km}^{2}$ for Kemadang and $16 \mathrm{~km}^{2}$ for Banjarejo Village and occupy $27 \%$ and $23 \%$ of the total Tanjungsari District respectively making them largest and the second-largest villages in it [27]. Both villages are located on the southern coast of Gunungkidul Regency and have many famous beaches like Baron, Kukup, Sepanjang, and Watukodok Beach. With total of 7025 residents and spread in its 17 sub-villages (dusun), Kemadang Village also the most populous village in Tanjungsari Districts. Meanwhile, Banjarejo population is 5439 and spread into 21 sub-villages. Most of the villagers in Kemadang and Banjarejo are small scalefarmers and also work in the informal tourism sector like a kiosk or small restaurant in the beach area. The research location is shown in Figure 2 below. 


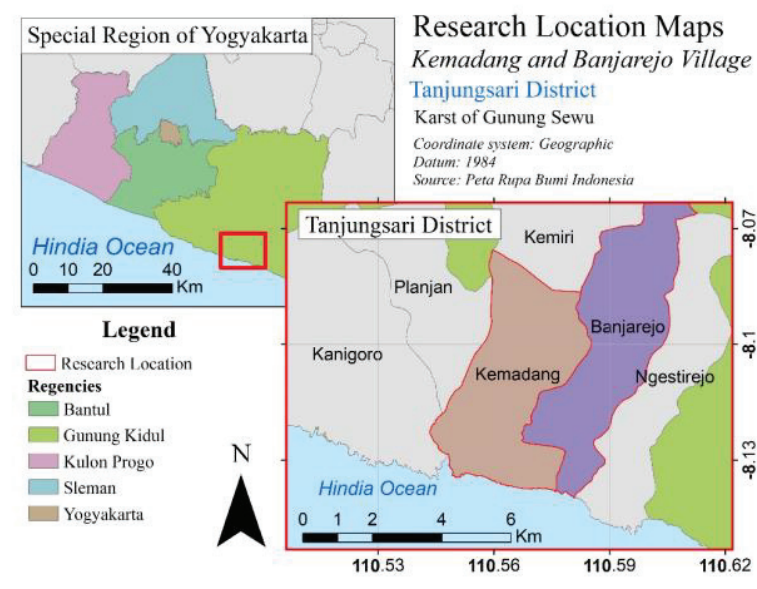

Fig. 2. Research Location Map (source: Analysis, 2021)

\subsection{Data Collection}

The data required for this research are divided into primary data of the location of 'Omah Alas', demography data, the profile of each 'Omah Alas' owners, and secondary data of Basic Geospatial Information in Rupabumi Maps (Peta RBI) including topography, land use, and transportation and monograph of Tanjungsari District. The primary data are obtained from a field survey conducted from January-March 2020 and the secondary data are obtained from an institutional survey or internet. During the field survey, the location of 'Omah Alas' is acquired by the plotting using GPS and the social data of demography and profile are collected by using in-depth interview using interview guidelines designed to conceive the relation between the owner with the 'Omah Alas' and the context of 'Omah Alas' in their environment.

We do purposive sampling or the sampling for certain criteria [28] for the farmers in the research location and select those whose daily life is mostly spent in the field hence satisfy the definition of Omah Alas. We manage to collect 30 samples of the houses located in the southern part of Kemadang and Banjarejo Village.

\subsection{Data Analysis}

The relation and context of Omah Alas will be analyzed using spatial analysis. Spatial analysis is a fruitful tool in seeing a Spatio-temporal dimension of phenomena and had been widely applied to examine the settlement in many fields of study [29]. In this research, the spatial analysis is only used to apprehend the spatial context related to the Omah Alas. Analysis of spatial elements of Omah Alas purposes to view the point spatial distribution of the settlement and used to help to describe the socio-cultural context of 'Omah Alas'.

For the spatial distribution pattern, we used nearest neighborhood analysis to determine the aggregation of Omah Alas location. The nearest neighborhood analysis consists of three patterns of clustered, random, and scattered patterns and calculated using equation (1)

$$
N_{n}=\frac{D_{o b s}}{\frac{1}{2} \sqrt{\frac{a}{n}}}
$$

with $N_{n}$ is the nearest neighbor value, $D_{o b s}$ is the mean of observed nearest neighbor, $\mathrm{a}$ is the area of observation and $\mathrm{n}$ is the total points. We also employed the Kernel Density to view the aggregate of the Omah Alas at the study area. Kernel Density works by using the radius of random features to determine the density [30]. It goes by equation (2).

$$
K D=\frac{1}{n h} \sum_{i=1}^{n} K\left(\frac{a-a_{i}}{h}\right)
$$

Where KD is the Kernel Density, $\mathrm{h}$ is the bandwidth, 1 is the point, and $\mathrm{n}$ is the number of points.

\section{Results and discussions}

\subsection{Spatial Distribution of Omah Alas}

\subsubsection{Village Setting}

The settlement pattern in the Karstic area differs from other landscapes due to the slow rate of development, low availability of land, density, and geomorphological setting. The map of the settlement pattern in study area displays the linear pattern along the main road. A relatively nucleated pattern is shown in the center of the village where the village administrative office is located. Omah Alas and the settlement at the field are dispersed due to the land setting and the number of settlers. This pattern is also affected by the main occupation of the residence. The nucleated pattern is dominated by farmers whose fields are located distances away.

People who live in the linear pattern of settlement along the Baron Road mostly open a small grocery store providing snacks and beverages for the passerby. This activity is boosted by the tourism activity where most of the visitors use Baron Road as the primary access whenever they visit the beach area. Meanwhile, the pattern for the Banjarejo Village is relatively more scattered than Kemadang Village due to a lack of economical activity. The village pattern of Kemadang and Banjarejo can be seen in Fig. 2 below. 


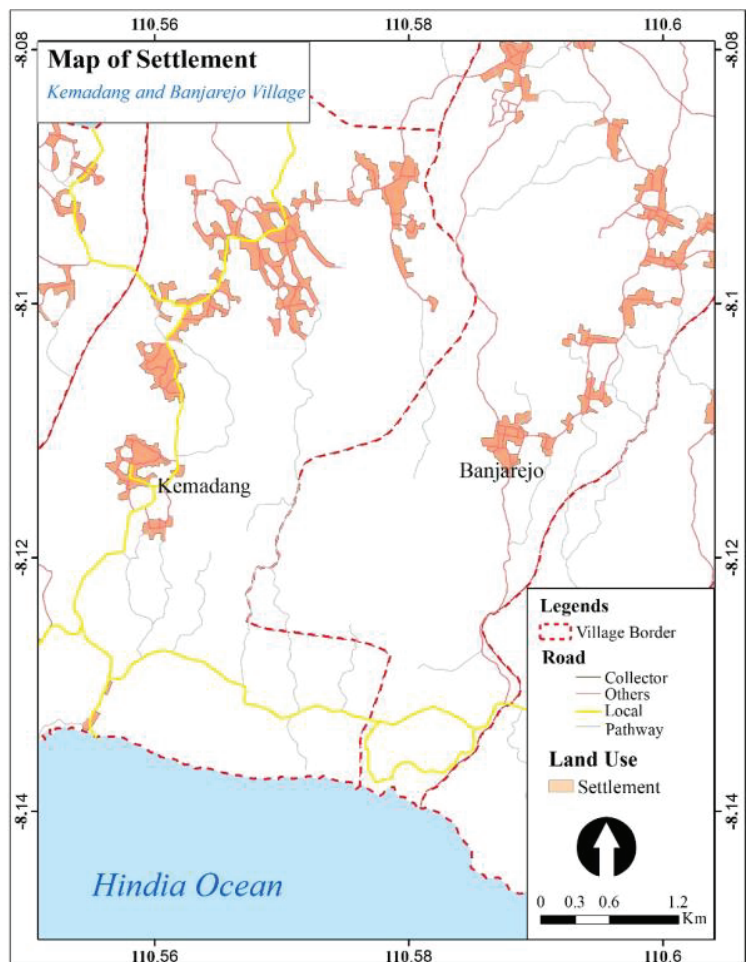

Fig. 3. Settlement Pattern of Kemadang Village (Source: Analysis, 2021)

Even though the administrative location of Omah Alas is on the Kemadang and Banjarejo Village. All of the Omah Alas dwellers have a house in the Kemadang Village. Therefore the factors that affect the Omah Alas location mostly originate from the Kemadang Village where the Omah Alas dwellers have their house and registered. Afterward, the condition of Kemadang Village as one of the primary tourism becomes one of the affecting factors. For this reason, we focus more on the Kemadang Village setting than Banjarejo.

The presence of tourism attraction particularly at Kemadang Village mixed with coastal and farming land creates various job sectors: agricultural, fisheries, and tourism. Each sector is then grouped into a particular sub-village or sector [31]. As the coastal area is located in the southern part of the village, people in the southern mostly work in the maritime or fisheries sector while people in the northern sector work in the agricultural sector. The division of the sector can be seen in Table 1 .

Table 1. Sectors of Activity at Kemadang Village

\begin{tabular}{|c|c|c|}
\hline Sector & Sub-Village & Activity \\
\hline $\begin{array}{c}\text { Central } \\
\text { Kemadang }\end{array}$ & $\begin{array}{c}\text { Kemadang Lor, Kemadang } \\
\text { Kidul, Pucung, Tenggang, } \\
\text { Nglaos, Karanglor, } \\
\text { Ngasem, Karangasem }\end{array}$ & Agricultural \\
\hline Kelor & Kelor Lor, Kelor Kidul & Agricultural \\
\hline Kayubimo & Kayubimo & Agricultural \\
\hline Sumuran & $\begin{array}{c}\text { Sumuran, Watubelah, } \\
\text { Kemadang Kulon }\end{array}$ & $\begin{array}{c}\text { Tourism, } \\
\text { Services }\end{array}$ \\
\hline Rejosari & Rejosari, Ngepung & $\begin{array}{c}\text { Maritime, } \\
\text { Tourism, } \\
\text { Services }\end{array}$ \\
\hline
\end{tabular}

(Source: [31], Analysis, 2021)

\subsubsection{Spatial Distribution of Omah Alas}

Kemadang Village pattern affects the properties of Omah Alas particularly the land ownership and the location of Omah Alas themselves. The agricultural subvillage is the Kelor and Central Kemadang sector and farmers from those sectors dominate the Omah Alas affecting linear patterns with direction to the south where the fields are mostly located. Farming activity is the main cause that attracts settlements to go souther. With most of the settlement is developed in the northern part, it consumes more space and land in the north and pushes farmers to move to the southern part hence causes Omah Alas to accumulate in the south. The settlement also develops following the morphological characteristic. From the maps shown in Figure 1, the settlement is adjusted according to the contour line. Morphology of Karst Gunung Sewu, especially in the research area is the polygonal karst [7] with lineaments of N-S and influenced by the tectonic movement and local fault. The spatial distribution can be seen in Fig. 3 below.

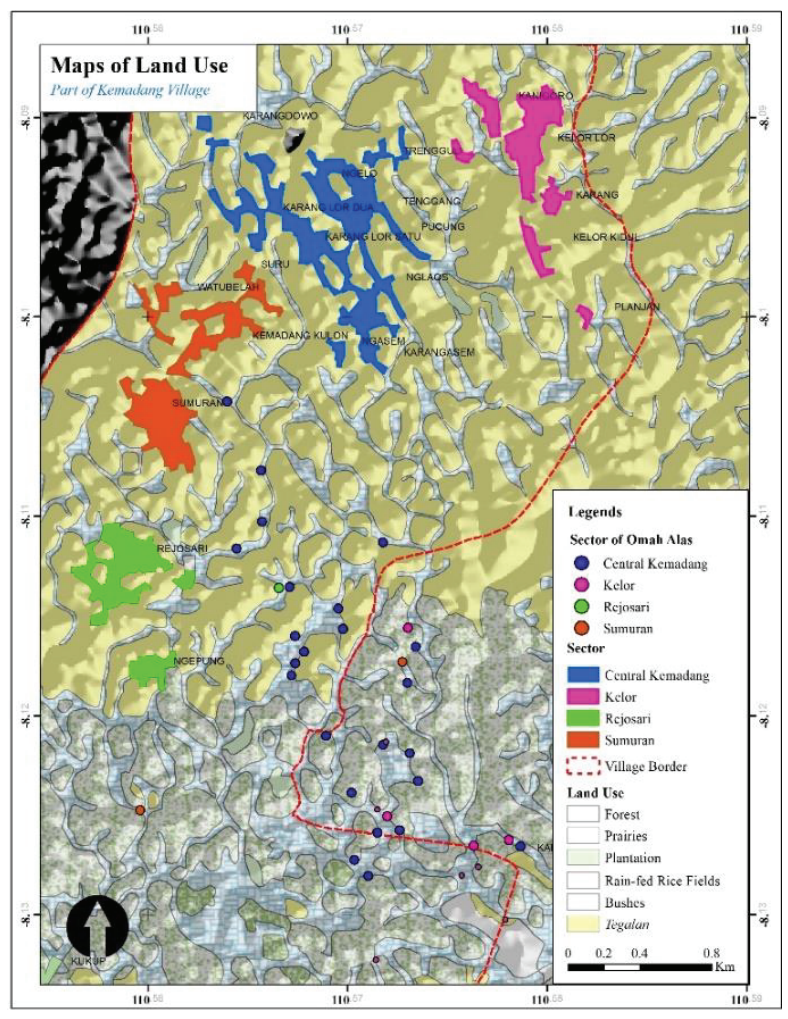

Fig. 4. Distribution of Omah Alas in Southern Part of Kemadang and Banjarejo Village (Source: Analysis, 2021)

We discovered 30 Omah Alas dispersed in the field. From these 30 Omah Alas, 9 of the dwellers stay in the Omah Alas a daily basis although they owe house in the village (dusun) while the others stay for only half a day and go back home when dusk and return to the field at dawn. Hence, the owner of Omah Alas can be divided into two categories: the full-time owners who stay overnights and half-time owners who use Omah Alas only as a resting place in the day and go home when dusk [23]. From these categories, the full-time owners mostly come from Central Kemadang and Kelor sectors. Farmers from those two sectors also own most of the 
field. To see how the aggregate of the Omah Alas, the Kernel Density Map could be seen on Figure 5.

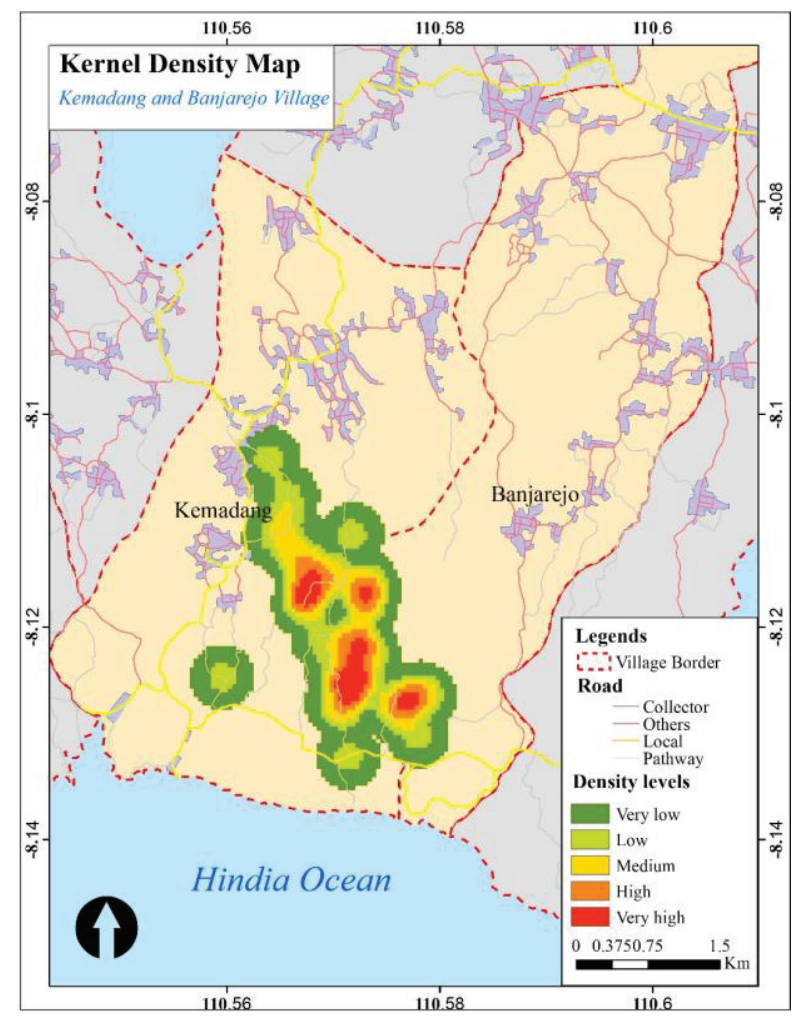

Fig. 5. Kernel Density Distribution of Omah Alas (Source: Analysis, 2021)

The Kernel Density map exhibits Omah Alas is denser in the borderline of the village. It also confirms that the southern the area, the more Omah Alas will be. There are several hotspots where Omah Alas are aggregated to a certain point.

From the settlement pattern, the Omah Alas in the south are the extension of the linear pattern of the Central Kemadang and Kelor sector. Meanwhile, the Rejosari and Sumuran sector farmers occupy a relatively small area in the eastern field of the sector and because of the temporality manners, the pattern of Rejosari and Sumuran are not too related to the presence of Omah Alas. To determine the spatial distribution pattern, we run the nearest neighborhood analysis, and the result is shown in Fig. 6 and Table 2 below.

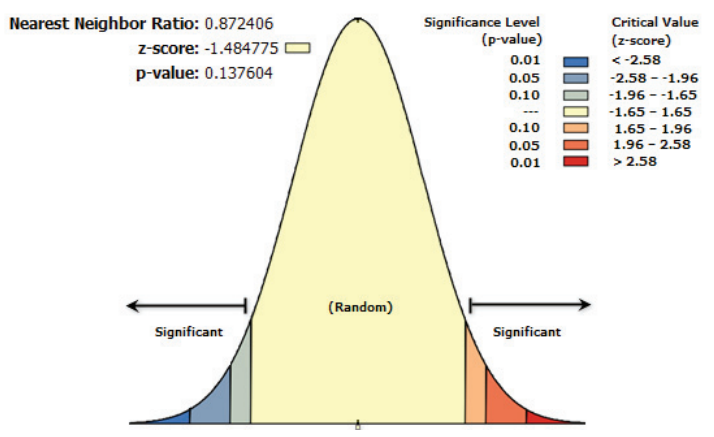

Fig. 6. Nearest Neighborhood Analysis Result (Source: Analysis, 2021)
Table 2. Results of Nearest Neighborhood Analysis

\begin{tabular}{|c|c|}
\hline Observed Mean Distance & 175.0803 Meters \\
\hline Expected Mean Distance & 200.6867 Meters \\
\hline Nearest Neighbor Ratio & 0.872406 \\
\hline Z-score & -1.484775 \\
\hline p-value & 0.137604 \\
\hline
\end{tabular}

(Source: Analysis, 2021)

The nearest neighborhood calculation generates the Observed Mean Distance at 175 meters. This is the number of the average distance between one Omah Alas to other Omah Alas and also the average length of the size of a doline in karst Gunung Sewu which shows how the landform influences the distance between Omah Alas. however, the $\mathrm{z}$-score of -1.48 is located on the insignificance area of the normal distribution of significant value which categorizes the spatial distribution into random pattern although the Omah Alas are mostly located in the closed depression. This could happen due to the irregularity of the landform in the karst area. The location of Omah Alas can be seen in Figure 7.

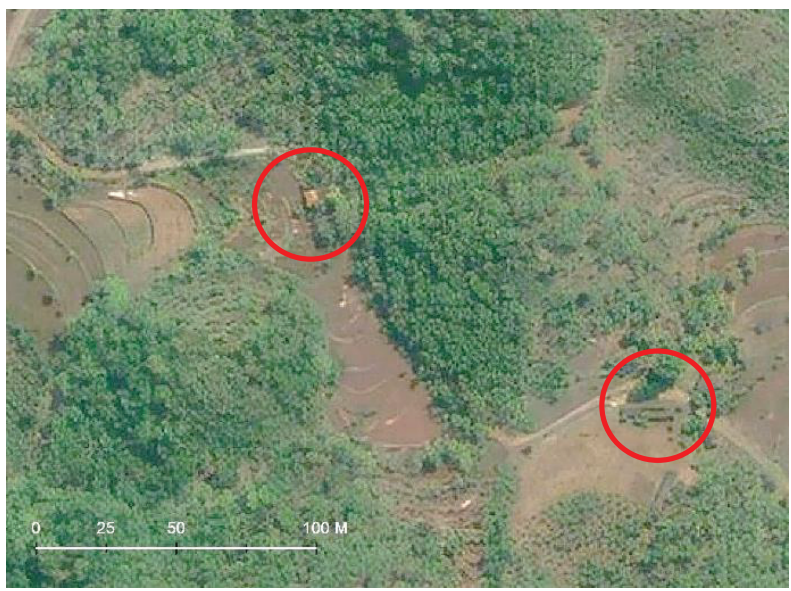

Fig. 7. Aerial View of Omah Alas (source: Google Earth Image and Analysis, 2021)

The random pattern also gives a clue on how the location of Omah Alas is chosen without considering the distance between other Omah Alas. Every Omah Alas dweller is pivoting only to their assets: land and livestock. Sharing workforce in daily work seldomly occurs and happens only when harvest season arrives and most of sharing work are done by involving family relationships like the farmer's children or relatives instead of the Omah Alas neighbor. This spatial pattern and distribution complements the previous study on spatial characteristics of Omah Alas which shows an individual pattern of Omah Alas and limited to the local settings [32].

\subsection{Omah Alas and Karst}

Omah Alas is a specific term and refers to the hut in the middle of the field that uses for semi-permanent settlements. It is a common phenomenon in the southern area of Karst of Gunung Sewu, specifically in 
Tanjungsari District. Tamimi, Rahmi, and Ikaputra [33] elaborates on how the Omah Alas as a building functions accordingly with agriculture as the inherent economical activities among the settlers. Omah Alas also serves the two types of daily livelihood: the settlers and the commuters. This pattern of daily livelihood is based on several considerations and yields some consequences. The picture of Omah Alas location setting example can be seen in Fig. 8.

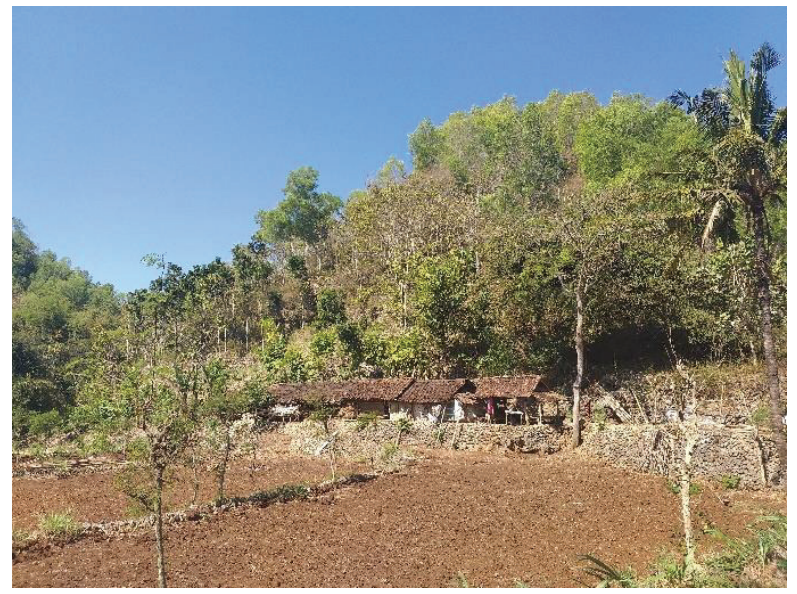

Fig. 8. Omah Alas at The Foothill (source: Documentation, 2021)

The reason for the settlers to stay on Omah Alas is mostly practical and related to the distance from the house in the village [23]. This is the first factor of the village setting. It would take time to go to the field in the dawn whereas they must be hasty to be in the field. If they got too late, the weather would be too hot to work, and it is considerably inconvenient for them. In addition, although they could use a mode of transportation such as a motorcycle or public transportation, they renounce that idea because they need to expend additional cost and not to mention some of them cannot ride the motorcycle. Another reason for the Omah Alas to stay in their field is due to the presence of pests that could demolish their plant. Unlike other fields, a threat for the farmers in Tanjungsari District is big mammals like monkeys or porcupines. Monkeys and their herd have become the biggest problem in recent years. They usually attack in the evening and cannot be stopped using regular equipment. Farmers must use fireworks to produce explosive sounds to repel the monkey. It requires full-time surveillance. For non-practical reasons, some Omah Alas settlers admit they feel serenity in the field while gazing at the plant and crop. They can enjoy themselves without burden or anxiety. Omah Alas contains dual functions for the settlers. Besides the dwelling and serves daily needs such as dishes, break, and night sleep, it also plays a role in supporting agricultural activities. Farmers build temporary storage (lumbung) for crop and livestock integrated with the main building since it would be much easier to manage and guard the crop and livestock if their place is adjacent.

The random dispersed pattern of Omah Alas is also affected by the irregularity point at the presence of doline or closed depression uniquely happens in the karst area or the morphological factor. Doline has a critical role for agricultural activity and livelihood since it is the only morphological unit in karst area that deposits soil and retains waters. The soil in karst area is terra rosa and originated from the weathering of limestone hence, this soil is very rich in calcium. Because the deposition of soil occurs in doline, the soil thickness is relatively higher and fits to be cultivated. Water is also considerably abundant in doline area. Rainfall that drops in the karst would flow into this depression and be collected securing water demand for the crop. Furthermore, flat and plain morphology in doline makes it easier to be adjusted and managed. A combination of these factors is the key factor for the agricultural setting in the karst area.

Regardless, sole contingency on doline is not enough and there's still space available at the conical hill slopes. Hillslope in the karst area is not suitable for agriculture plants like paddy or corn as the main commodity. It has very thin soil because the soil material is constantly eroded and washed away to the doline and the slope also tackles cultivation. Farmers in Karst of Gunung Sewu overcome these obstacles by building terrasering system [34]. To retain soil and water on the terrace. Nevertheless, this method doesn't work well on paddy and corn because it still can be easily swept away by the water flow which runs fast on slopes thus farmers plant hardwood trees like teaks or acacias. This system had already been shown by Nibbering [34] and he divided this as low-land agriculture and high-land agriculture.

Another factor that influences the spatial pattern is land ownership. The limited land resource makes the land distribution is considerably hard to be done. Physical barriers such as karstic hills create a constraint in dividing farming land into the same amount. Hence, the farmers who want to expand their land must accuse irregular forms to achieve the area they need. Further, omah alas an only be built on the righteous property hence make its distribution is in accordance to the land ownership.

In short, the factors that affected Omah Alas spatial distribution is shown in Table 3.

Table 3. Factors in the Spatial Distribution of Omah Alas

\begin{tabular}{|c|c|c|}
\hline No & Factors & Explanation \\
\hline 1 & Village settings & $\begin{array}{c}\text { Field and the house in the } \\
\text { permanent settlement is } \\
\text { distant. }\end{array}$ \\
\hline 2 & Morphology & $\begin{array}{c}\text { Omah Alas's location } \\
\text { follows flat morphology } \\
\text { and is located in doline as } \\
\text { the most suitable } \\
\text { morphology for cultivation } \\
\text { with its thick soil and water } \\
\text { retention. }\end{array}$ \\
\hline 3 & Land use & $\begin{array}{c}\text { Omah Alas are bounded in } \\
\text { the agricultural land use } \\
\text { due to the high numbers of } \\
\text { agricultural activities }\end{array}$ \\
\hline 4 & Land ownership & $\begin{array}{c}\text { Omah Alas can only be } \\
\text { built on the righteous } \\
\text { properties. }\end{array}$ \\
\hline
\end{tabular}

(Source: [32], Analysis, 2021) 
The aggregate of Omah Alas forms a social and certain neighborhood network and becomes a unique pattern. A study on settlement patterns by Kaho and Giyarsih [22] evaluates how the house's qualities in karst area but are only limited to the village area and does not take the Omah Alas type into account. Another research in the settlement pattern at karst area of Pati, conducted by Anatasari and Pradoto [21] suggests that settlement in karst area tends to approach a water source. However, because of the difference in hydrological characteristics, Omah Alas at Karst of Gunung Sewu is not attracted to water sources. There are barely any water sources in the surrounding area of Omah Alas and for domestic needs, the settlers rely on the rainwater container (Penampung Air Hujan (PAH)).

Moreover, we argue that Omah Alas will be hardly developed into a village or settlement due to the remoteness and agricultural land/space demand; they are not the seed of settlement. This argumentation lays on the fact that the surrounding land of Omah Alas is private ownership and has been used as crop fields. However, with the very rapid infrastructure expansion in the coastal region, houses will be vastly emerge causing land-use change. Rapid development in the village and transition to the higher level (village to a small town) also may cause the development although in the karst area, the development will be driven mainly by the morphological features as shown in the China karst where the rural-urban relationship is heavily configured by the elevation aspect [35]. Nevertheless, with the relatively similar altitude, the development in the Karst of Gunung Sewu and the case of Omah Alas will be more driven by the presence of doline and karstic hills for the path or access of interaction between the two regions. A further and thorough observation is desperately required to trace the evolution of Omah Alas into a further form.

\section{Conclusion}

We conclude that Omah Alas are distributed in the random pattern and aggregated in the southern part of the research location where several high densities are found with the average distance among the Omah Alas is 175 meters. This pattern is influenced by the physical factor of the Karst Area and the settlement pattern in Kemadang Village as the host-village of Omah Alas. The settlement pattern of Omah Alas is also affected by the land use and the land ownership where the Omah Alas are only located in the agricultural land use and in the righteous properties or ownership of the land.

We thank Kemadang Village residents for their hospitality and willingness to provide the data we need. The data are also part of the Shabrina Tamimi's thesis titled “Arsitektur Omah Alas Petani Subsisten di Desa Kemadang, Gunungkidul”.

\section{References}

1. E. Burri, B. Castiglioni, U. Sauro, Int. J. Speleol. 28, 33 (1999)

2. L. Song, Int. J. Speleol. 28, 139 (1999)
3. D. Gillieson \& M. Thurgate, Int. J. Speleol. 28, 149 (1999)

4. I. Bárány-Kevei, Int. J. Speleol. 28, 89 (1999)

5. G. Veni, H. DuChene, N. C. Crawford, C. G. Groves, G. N. Huppert, E. H. Kastning, R. Olson, B. J. Wheeler, Living with Karst: A Fragile Foundation (American Geological Institute, 2001)

6. P. Forti, The scientific and socio-economic importance of karst and caves and their vulnerability, in Brief for GSDR (2015)

7. E. Haryono, M. Day, J. of cave and karst studies 66, 62 (2004)

8. H. D. Tjia, Indonesian J. on Geoscience 8, 75 (2013)

9. A. Sunkar, Media Konservasi 13, 1 (2008)

10. H. Reinhart, A. Rifani, Jurnal Ilmu Lingkungan 17, 2 (2019)

11. M. Baiquni, Livelihood Strategy of The Community in A Karst Village, Gunung Sewu, Indonesia in Proceedings Asian TransDisciplinary Karst Conference, Yogyakarta, January 7-10th (2011)

12. J. C. Scott, Moral Ekonomi Petani: Pergolakan dan Subsistensi di Asia Tenggara (LP3ES, 1976)

13. C. Coxon, Agriculture and Karst in P. E. van Betnen (ed.), Karst Management, Springer, Dordrecht (2011)

14. E. D. Suryanti, Sudibyakto, M. Baiquni, Jurnal Kebencanaan Indonesia 2, 3 (2010)

15. W. Widiyanti, A. Dittman, Procedia Environmental Sciences 20, 693 (2014)

16. H. Uhlig, GeoJ. 4, 31 (1980)

17. R. A. Suwasono, P. Mateus, Sutedjo, IOP Conf. Series: Earth and Environmental Science 144 (2018)

18. P. Toth, P. Demjan, K. Griacova, Documenta Praehistorica 38, 307 (2011)

19. P. V. Kirch, A. S. Hartshorn, O. A. Chadwick, P. M. Vitousek, D. R. Sherrod, J. Coil, L. Holm, W. D. Sharp, Environment, agriculture, and settlement patterns in a marginal Polynesian landscape in Proceedings of the National Academy of Sciences 101, 9936 (2004)

20. P. Khadiyanta, S. Dewantari, Settlement adaptation by reshaping dwellings in the degrading area at Genuk Disctrict of Semarang City, Indonesia in Proceeding of International Conference, Intelligent Planning Towards Smart Cities, 3-4 November 2015, Surabaya, Indonesia, (2016)

21. A. T. Anatasari, W. Pradoto, Jurnal Pembangunan Wilayah \& Kota 12, 251 (2016)

22. H. E. D. P. R. Kaho, S. R. Giyarsih, Jurnal Bumi Indonesia 7, 1 (2018)

23. S. Tamimi, Arsitektur Omah Alas Petani Subsisten di Desa Kemadang, Gunungkidul (Thesis, Department of Architecture and Regional Planning 
Faculty of Engineering Universitas Gadjah Mada, 2020)

24. D. C. Ford, P. Williams, Karst Hydrogeology and Geomorphology (John Wiley \& Sons, 2007)

25. E. Haryono, Suratman, Significant Features Of Gunung Sewu Karst As Geopark Site in 4th International UNESCO Conference on Geopark, April 12-15, 2010, Langkawi (2010)

26. T. Simanjuntak, Gunung Sewu in prehistoric times (Gadjah Mada University Press, 2002)

27. BPS, Kecamatan Tanjungsari Dalam Angka 2018, (2019)

28. M. Singarimbun, S. Effendi, Metode Penelitian Survai (LP3ES, 1982)

29. H. Subagio, R. H. Koestoer, Y. M. Zagloel, L. Darmajanti, IOP Conf. Series: Earth and Environmental Science 280 (2019)

30. N. U. Khan, W. Wan, S. Yu, ISPRS Int. J. GeoInf. 9, 70 (2020)

31. I. Fauzi, G. Radjiman, Antara Dua Dunia: Strategi Bertahan Hidup Penduduk Desa Kemadang, Kecamatan Tanjungsari, Kabupaten Gunungkidul, (Thesis, Department of Architecture and Regional Planning Faculty of Engineering Universitas Gadjah Mada, 2014) https://repository.ugm.ac.id/131086/

32. S. Tamimi, D. H. Rahmi, Omah Alas as an Adaptive Dwelling in Karst Area: Spatial Characteristics, J. Built Env. Studies 1, 45 (2020)

33. S. Tamimi, D. H. Rahmi, Ikaputra, Journal of Architectural Discourses 17, 104 (2020)

34. J. W. Nibbering, Upland cultivation and soil conservation in limestone regions on Java's south coast: Three historical case-studies in P. Boomgaard, F. Colombijn, and D. Henley (ed.) Paper Landscapes explorations in the environmental history of Indonesia (KITLV Press, 1997)

35. J. Li, Z. Cai, L. Duan, J. Earth Sci. Res. J. 24, 267 (2020) 